\title{
ANALYSIS OF STOMACH CONTENTS IN GREEN BACK MULLET, CHELON SUBVIRIDIS FROM MERBOK ESTUARY, MALAYSIA
}

\author{
Kaniz Fatema*, Wan Maznah Wan Omar ${ }^{1}$ and Mansor Mat Isa ${ }^{1}$ \\ Department of Fisheries, University of Dhaka, Dhaka-1000, Bangladesh
}

Greenback Mullet, Chelon subviridis (Nalenciennes, 1836) is a member of the family Mugilidae occurring in the fresh, brackish and coastal marine waters of the tropical and subtropical regions. This family recognized due to its highly specialized adaptation of feeding on surface sediments associated with organic components (Odum 1970). Stomach contents analysis of animals are the corner stones for explaining the nutritional requirements and their interactions with other organisms (Windell and Bowen 1978). Research publication on feeding habit of this mullet was in Malaysia especially on Merbok is very scarce.

In the present study, fish samples were collected from the upstream of Lalang and Sameling River from January to December 2011 on monthly interval. The samples were collected from artisanal fishermen who operate the barrier nets, with the dimensions of the net at $100-120 \mathrm{~m}$ long, $3-5 \mathrm{~m}$ deep, and with $2.5 \mathrm{~cm}$ mesh size and without bunt. Fishing operations were carried out 3-4 days before and after the full moon and new moon associated with spring tides of the month. Fishing activities were normally halted during neap tides. During the low tide nets were set by anchoring the bottom rope to the river bed. Then the head rope was raised and secured to poles during the high water. Finally, the fish was harvested during the low-water period for about $12 \mathrm{~h}$ after the net was set. Before transporting the fish samples to the laboratory for further analysis, they were preserved in labeled polyethylene bags with $10 \%$ formalin to prevent digestion of food materials and to stop the enzymatic activity of the stomach contents.

The stomach contents were analyzed following two methods:

(i) Numerical method: In numerical method, at first the number of individuals in each food category was recorded for all stomachs. Then, the total was expressed as a proportion, usually a percentage, of the total individuals in all food categories (Ikusemiju and Olaniyan 1977).

The mean number of individuals per stomach in each food category was calculated.

\footnotetext{
* Author for correspondence: *Department of Fisheries, University of Dhaka, Dhaka-1000, Bangladesh $<$ f.kaniz@yahoo.com>. 1School of Biological Sciences, Center for Marine and Coastal Studies (CEMACS), Universiti Sains Malaysia, 11800 Penang, Malaysia.
} 
(ii) Frequency of occurrence method: Frequency of occurrence method is a way of recording data gleaned from stomach contents for calculating the number of stomachs containing one or more individuals of each food category. This number was then expressed as a percentage of all stomachs or all those containing food. Frequency of occurrence was calculated according to the formula by Hyslop (1980) and Bowen (1983): $F i=(n i / n)^{*}$ 100, Where, Fi: frequency of occurrence of the $i$ food item in the sample, ni: number of stomachs in which the $i$ item is found, $n$ : total number of stomachs with food in the sample.

Stomach food contents of $C$. subviridis are showed in Table 1. Eight major groups were identified and these were diatoms, cyanobacteria, desmids, plant materials, zooplankton, detritus, sand grains and pisces. In C. subviridis, plant materials constitute the most important food item by numerical method (65.32\%), while diatom (Nitzschia sp., Navicula sp., Chaetoceros sp., Coscinodiscus sp., Epithemia sp., Gyrosigma sp., Cyclotella sp., Pleurosigma sp., Fragillaria sp., Meridion sp., Melosira sp., Surirella sp., Pinnularia sp., Cymbella sp. and unidentified) formed the most frequently consumed food item by the occurrence method (37.89\%), respectively.

Table 1. The stomach contents of Chelon subviridis $(n=225)$ from the Merbok estuary Malaysia

\begin{tabular}{|c|c|c|c|c|}
\hline \multirow[b]{2}{*}{ Food Items } & \multicolumn{2}{|c|}{ Numerical method } & \multicolumn{2}{|c|}{ Occurrence method } \\
\hline & No. of individual & $\%$ & No. of individual & $\%$ \\
\hline \multicolumn{5}{|l|}{ Diatoms } \\
\hline Nitzschia sp. & 324 & & 133 & \\
\hline Navicula sp. & 281 & & 113 & \\
\hline Chaetoceros sp. & 366 & & 120 & \\
\hline Coscinodiscus sp. & 14 & & 11 & \\
\hline Epithemia sp. & 12 & & 12 & \\
\hline Gyrosigma sp. & 416 & & 125 & \\
\hline Cyclotella sp. & 1244 & & 188 & \\
\hline Pleurosigma sp. & 114 & & 40 & \\
\hline Fragillaria sp. & 15 & & 14 & \\
\hline Meridion sp. & 1 & & 1 & \\
\hline Melosira sp. & 13 & & 6 & \\
\hline Surirella sp. & 4 & & 3 & \\
\hline Pinnularia sp. & 10 & & 5 & \\
\hline Cymbella sp. & 1 & & 1 & \\
\hline Unidentified & 127 & & 24 & \\
\hline
\end{tabular}




\begin{tabular}{|c|c|c|c|c|}
\hline Total & 2942 & 22.67 & 796 & 37.89 \\
\hline \multicolumn{5}{|l|}{ Cyanobacteria } \\
\hline Oscillatoria sp. & 553 & & 115 & \\
\hline Spirogyra sp. & 36 & & 27 & \\
\hline Spirulina sp. & 261 & & 67 & \\
\hline Anabaenopsis sp. & 33 & & 17 & \\
\hline Scenedesmus sp. & 1 & & 1 & \\
\hline Unidentified & 26 & & 17 & \\
\hline Total & 910 & 6.88 & 244 & 11.61 \\
\hline \multicolumn{5}{|l|}{ Desmids } \\
\hline Closterium sp. & 18 & & 11 & \\
\hline Penium sp. & 17 & & 16 & \\
\hline Total & 35 & 0.265 & 27 & 1.29 \\
\hline Plant materials & 8643 & 65.32 & 209 & 9.95 \\
\hline Total & 8643 & 65.32 & 209 & 9.95 \\
\hline \multicolumn{5}{|l|}{ Zooplankton } \\
\hline Polycheates & 226 & & 107 & \\
\hline Molluscs & 67 & & 52 & \\
\hline Nematods & 64 & & 58 & \\
\hline Rotifer & 21 & & 18 & \\
\hline Oikopleura & 4 & & 4 & \\
\hline Daphnia sp. & 2 & & 2 & \\
\hline Copepod & 81 & & 70 & \\
\hline Copepod appendages & 181 & & 118 & \\
\hline Argulus sp. & 9 & & 9 & \\
\hline Coelenterates & 3 & & 3 & \\
\hline Larva & 31 & & 19 & \\
\hline Total & 689 & 5.21 & 460 & 21.89 \\
\hline Detritus & - & - & 209 & 9.95 \\
\hline Total & - & - & 209 & 9.95 \\
\hline Sand grains & . & & 147 & 7 \\
\hline Total & - & - & 147 & 7 \\
\hline Pisces (bones, scales) & 12 & 0.091 & 9 & 0.428 \\
\hline Total & 12 & 0.091 & 9 & 0.428 \\
\hline
\end{tabular}


Zooplankton made up $5.21 \%$ and $21.89 \%$ of the stomach content measured by numerical and occurrence methods, respectively, while pisces (bones, scales) constitute 0.091 and $0.428 \%$ by numerical and occurrence methods, respectively (Table1). The least consumed food item was the pisces and desmids in the stomach of fish species. Detritus was the most eaten item and was prominent by occurrence method. Detritus constitute $9.95 \%$ and sand grains consist of 7.00 \%by occurrence method in this fish species (Table 1). Plant materials were important constituents, after the diatom and zooplankton by both the numerical and occurrence methods. By numerical method, plant materials were the most abundant food item in the Merbok estuary during the study period. Other food items of importance consumed by Chelon fish species included the diatoms, which was more abundant than the cyanobacteria, as shown by numerical and occurrence methods.

Stomach content analysis using both frequency of occurrence and numerical method of Chelon subviridis identified plant materials, diatoms and detritus as predominant food items in most months during the study period. However, in numerical method detritus and sand grains could not be counted. Therefore, frequency of occurrence method is useful for qualitative analysis of stomach content whereas numerical method is mostly preferred for quantitative assessment.

\section{LITERATURE CITED}

BOWEN, S. H. 1983. Quantitative description of the diet. In : Nilesen, L,A.; Johnson, D.L. (ed.) Fisheries techniques. Maryland: American Fisheries Society: 325-336.

HYSLOP, E. 1980. Stomach contents analysis-a review of methods and their application. J. Fish Biology, 17(4): 411-429.

IKUSEMIJU, K. and OLANIYAN, C. 1977. The food and feeding habits of the catfishes, Chrysichthys walkeri (Gunther), Chrysichthys filamentosus (Boulenger) and Chrysichthysnigrodigitatus (Lacépède) in the Lekki Lagoon, Nigeria. J. Fish Biology, 10(2): 105-112.

ODUM, W. E. 1970. Utilization of the direct grazing and plant detritus food chains by the striped mullet mugil cephalus, in Marine Food Chains, J. H. Steele (Ed.). London: Olivier and Boyd.

WINDELL, J. T. and BOWEN, S. H. 1978. Methods for study of fish diets based on analysis of stomach contents. In : Methods for assessment of fish production in freshwaters. (Ed. T. Bagenal), IBH Hanbook no.3. Oxford: Blackwell Scientific Publications. 